Jurnal Agro 8(2), 2021

\title{
PERBEDAAN PERTUMBUHAN DAN PRODUKTIVITAS VARIETAS BAYAM HIJAU DAN BAYAM MERAH
}

\section{DIFFERENCES IN GROWTH AND PRODUCTIVITY OF GREEN AND RED SPINACH VARIETIES}

\author{
Arya Widura Ritonga*, Muhammad Syaifuk Ar Rosyid, Axel Anderson, Muhamad Achmad \\ Chozin, Purwono
}

Departemen Agronomi dan Hortikultura, Fakultas Pertanian, IPB University, Bogor, Jawab Barat, Indonesia

*Korespondensi : aryaagh@apps.ipb.ac.id

Diterima : 24 Oktober 2021 / Disetujui : 21 Desember 2021

\begin{abstract}
ABSTRAK
Bayam termasuk salah satu sayuran terpenting di Indonesia karena paling banyak dikonsumsi setelah kangkung. Bayam hijau dan bayam merah merupakan jenis bayam paling banyak ditanam dan dikonsumsi. Penelitian ini bertujuan untuk mengetahui perbedaan pertumbuhan dan produktivitas varietas bayam hijau dan bayam merah. Penelitian dilakukan pada Februari April 2021 di Kebun Percobaan Leuwikopo, Departemen Agronomi dan Hortikultura, Fakultas Pertanian, IPB University. Sebanyak 9 varietas bayam hijau (Maryland, Richie, Maestro, Benua, Doly, Khanafiah, Manila, Pacific, White Leaf) dan 4 varietas bayam merah (Mira, Baret Merah, Clara, Aurora) ditanam menggunakan rancangan kelompok lengkap teracak dengan tiga ulangan. Hasil penelitian memperlihatkan bahwa varietas bayam hijau memiliki kandungan persentase warna hijau daun lebih banyak namun memiliki persentase warna biru dan merah yang lebih rendah dibandingkan varietas bayam merah. Hasil penelitian juga memperlihatkan bahwa varietas bayam hijau menghasilkan tinggi tanaman dan produktivitas yang lebih baik dibandingkan varietas bayam merah, namun varietas bayam merah menghasilkan luas daun dan jumlah daun per tanaman saat panen yang lebih baik besar dibandingkan varietas bayam hijau. Varietas White Leaf merupakan varietas bayam yang sangat baik karena memiliki persentase warna hijau daun yang tinggi, luas daun yang besar dan produktivitas yang tinggi.
\end{abstract}

Kata kunci: Antosianin, Bayam, Klorofil, Produksi

\begin{abstract}
Spinach is one of the most important vegetables in Indonesia because it was the second most consumed after kangkung. Green spinach and red spinach are the most widely grown and consumed types of spinach. This study aimed to determine differences in growth and productivity between varieties of green spinach and red spinach. The research was conducted in February - April 2021 at the Leuwikopo Experimental Field, Department of Agronomy and Horticulture, Faculty of Agriculture, IPB University. A total of nine varieties of green spinach and four varieties of red spinach were planted using a completely randomized block design with three replications. The results showed that the green spinach variety contained a higher percentage of grenn leaf color but had a lower percentage of blue and red leaf color than the
\end{abstract}

ISSN : 2407-7933

286

Cite this as: Ritonga, A, W., Ar Rosyid, M, S., Anderson, A., Chozin, M, A., \& Purwono. (2021). Perbedaan pertumbuhan dan produktivitas varietas bayam hijau dan bayam merah. Jurnal Agro, 8(2), 286-297. https://doi.org/10.15575/14664 
red spinach varieties. The results also showed that the green spinach varieties produced better plant height and productivity than the red spinach varieties, but the red spinach produced better leaf area and a number of leaves per plant at harvest than the green spinach. The White Leaf variety is the excellent spinach variety because it has a high percentage of green leaf color, large leaf area, and high productivity.

Key words : Anthocyanin, Chlorophyll, Production, Spinach.

\section{PENDAHULUAN}

Bayam dengan tingkat konsumsi 9,26 g per kapita per hari merupakan sayuran kedua paling banyak dikonsumsi di Indonesia setelah kangkung dengan konsumsi $10.46 \mathrm{~g}$ per kapita per hari (BPS, 2019). Tanaman bayam banyak dibudidayakan karena umur panennya yang singkat (21 - 30 HST) dan mudah dibudidayakan oleh petani di Indonesia (Zuryanti et al., 2016). Bayam hijau mengandung $39,9 \mathrm{~g}$ protein, $358 \mathrm{mg}$ kalsium, 2,4 mg besi, 0,8 mg seng, $18 \mathrm{mg}$ vitamin $\mathrm{A}$, $62 \mathrm{mg}$ vitamin $\mathrm{C}$ dalam tiap $100 \mathrm{~g}$ daun bayam (Zuryanti et al., 2016). Hal ini menjadikan tanaman bayam sebagai salah satu tanaman sayuran penting di Indonesia.

Bayam yang ditanam atau dikonsumsi di Indonesia umumnya berwarna hijau. Namun, bayam berwarna merah juga mulai banyak ditanam dan dikonsumsi masyarakat (Rachmania \& Ashari, 2019). Bayam merah disukai konsumen karena memiliki kandungan komponen antioksidan antara lain betalain, karotenoid, vitamin C, flavanoid, dan polifenol. Komponen antioksidan tersebut mempunyai potensi menurunkan kadar timbal di dalam darah sehingga mampu mencegah efek toksisitasnya (Wiyasihati \& Wigati, 2016; Rahayu et al., 2013). Bayam merah disukai oleh petani karena harga jualnya dapat lebih mahal dibandingkan bayam hijau (Rachmania \& Ahasri, 2019).

Adanya perbedaan warna daun pada varietas bayam hijau dan bayam merah diduga mempengaruhi perbedaan pertumbuhan dan daya hasil dari jenis bayam tersebut. Bayam hijau diduga memiliki kandungan klorofil yang lebih tinggi dibandingkan bayam merah. Terdapat korelasi yang nyata antara tingkat kehijauan daun terhadap kandungan klorofil a, klorofil b dan total klorofil dalam daun (Jiang et al., 2017). Klorofil merupakan salah satu komponen utama dalam proses fotosintesis yang mempengaruhi pertumbuhan dan daya hasil tanaman (Manurung et al., 2020). Namun demikian, informasi perbedaan pertumbuhan dan daya hasil antara bayam hijau dan bayam merah belum banyak ditemukan. Penelitian ini bertujuan untuk mengetahui perbedaan pertumbuhan antara varietas bayam hijau dan bayam merah.

\section{BAHAN DAN METODE}

Penelitian dilakukan pada Februari - April 2021 di Kebun Percobaan Leuwikopo, Departemen Agronomi dan Hortikultura, Fakultas Pertanian, Institut Pertanian Bogor. Sebanyak 9 varietas bayam hijau (Varietas Maryland, Richie, Maestro, Benua, Doly, Khanafiah, Manila, Pacific, dan White Leaf) dan 4 varietas bayam merah komersial (Varietas Mira, Baret Merah, Clara, Aurora) ditanam menggunakan rancangan kelompok lengkap teracak dengan tiga ulangan sehingga dihasilkan 3 satuan percobaan.

Dua minggu sebelum penanaman dilakukan penggemburan tanah, pembuatan 
bedengan, aplikasi $10 \mathrm{t} \mathrm{ha}^{-1}$ pupuk kandang, dan aplikasi $2 \mathrm{t} \mathrm{ha}^{-1}$ kapur pertanian. Setiap plot satuan percobaan berukuran $1 \mathrm{~m} \times 1 \mathrm{~m}$. Penanaman dilakukan dengan sistem alur tanam dengan jarak antar alur berukuran 15 $\mathrm{cm}$ sehingga terdapat 5 alur tanam pada setiap satuan percobaan. Benih bayam sebanyak $1 \mathrm{~g}$ per satuan percobaan disebar pada setiap alur secara merata. Pumupukan dilakukan dua kali yaitu pupuk dasar dan pupuk susulan. Pupuk dasar diberikan pada 1 minggu setelah tanam (MST) yang terdiri atas $30 \mathrm{~g} \mathrm{~m}^{-2}$ urea, $20 \mathrm{~g} \mathrm{~m}^{-2} \mathrm{TSP}$, dan $10 \mathrm{~g} \mathrm{~m}^{-2}$ $\mathrm{KCl}$ yang diaplikasikan dengan diantara alur tanaman. Pemupukan susulan dilakukan pada saat tanaman berumur 3 MST menggunakan pupuk NPK 16-16-16 (konsentrasi $5 \mathrm{~g} \mathrm{~L}^{-1}$ ) yang diaplikasikan secara kocor sebanyak $1 \mathrm{~L} \mathrm{~m}^{-2}$. Pemeliharaan yang dilakukan terdiri atas penyiraman, penyiangan gulma, dan pengendalian OPT. Penyiraman dilakukan setiap pagi dan sore hari. Penyiangan gulma dilakukan dengan cara manual sesuai dengan pertumbuhan gulma. Pengendalian OPT dilakukan dengan cara manual. Bayam dipanen saat 50\% populasi tanaman telah memiliki tinggi minimal $20 \mathrm{~cm}$. Pemanenan dilakukan dua kali secara bertahap dengan mencabut tanaman beserta akar tanaman.

Karakter pengamatan yang diamati pada penelitian ini terdiri atas \% Red Blue Green (\% RGB) daun, tinggi tanaman (cm), umur panen, jumlah daun saat panen, diameter batang $(\mathrm{mm})$, panjang daun $(\mathrm{cm})$, lebar daun $(\mathrm{cm})$, luas daun $\left(\mathrm{cm}^{2}\right)$, panjang tangkai daun $(\mathrm{cm})$, bobot per tanaman $(\mathrm{g})$, bobot per petak (g) dan produktivitas (t ha ${ }^{-1}$ ). Pengamatan bobot per tanaman dan bobot per petak dilakukan terhadap satu tanaman bayam utuh (daun dan batang). Pengamatan $\%$ RGB daun dilakukan dengan memfoto daun di studio mini dengan pencahayaan, jarak dan kamera yang sama lalu dianalisis menggunakan perangkat lunak ImageJ (https://imagej.nih.gov/ij/). Produktivitas tanaman dihitung menggunakan bobot per petak.

Analisis ragam dilakukan terpisah pada varietas bayam hijau dan varietas bayam merah yang dilanjutkan dengan uji lanjut BNJ pada taraf $\alpha 5 \%$. Analisis ragam dan uji lanjut BNJ dilakukan menggunakan PKBT STAT 3.1 (http://pbstat.com/pkbt-stat/). Uji kontras dilakukan untuk membandingkan pertumbuhan antara varietas bayam hijau dan varietas bayam merah. Uji contrast dilakukan menggunakan perangkat lunak SAS 9.1 dengan taraf $\alpha 5 \%$.

\section{HASIL DAN PEMBAHASAN}

Hasil analisis persentase warna merah, hijau dan biru (\% RGB) memperlihatkan adanya perbedaan \% RGB antar varietas bayam hijau namun tidak terdapat perbedaan \% RGB antar varietas bayam merah. Persetase warna merah, hijau dan biru pada varietas bayam hijau berturutturut dihasilkan oleh varietas White leaf, Benua dan Khannafiah (Tabel 1). Reddy et al. (2014) melaporkan bahwa warna daun 6 aksesi landrace bayam India bervariasi dari hijau terang sampai dengan hijau gelap. Pebrianti et al. (2015) melaporkan bahwa seluruh varietas bayam merah (varietas Clara, Delima, Abbang, Red Leaf, Baret Merah dan Red Spinach) yang dievaluasi memiliki warna daun yang cukup seragam yaitu merah keunguan. Satriyono \& Ashari, (2019) juga melaporkan bahwa warna daun genotipe bayam merah berkisar antara merah tua sampai dengan merah keunguan.

Hasil uji kontras menunjukkan bahwa terdapat perbedaan \% RGB antara warna daun varietas bayam hijau dan bayam merah 
(Tabel 1 dan Gambar 1). Persentase warna hijau $(52,34-56,98 \%)$ daun varietas warna bayam hijau lebih tinggi dibandingkan varietas bayam merah $(26,97-27,73 \%)$ mengindikasikan adanya kandungan klorofil yang lebih tinggi pada varietas bayam hijau dibandingkan varietas bayam merah. Sementara itu, lebih tingginya persentase warna merah $(45,34$ - 46,58\%) dan biru $(26,45-26,93 \%)$ pada daun varietas bayam merah dibandingkan varietas bayam hijau mengindikasikan adanya kandungan antosianin yang lebih tinggi pada daun varietas bayam merah dibandingkan varietas bayam hijau (Gambar 1).
Jiang et al. (2017) melaporkan adanya korelasi yang nyata dan positif antara warna hijau daun yng diukur dengan SPAD meter dengan kandungan klorofil $a$, klorofil $b$ dan total klorofil dalam daun tomat. Sementara itu, Pebrianti et al. (2015) melaporkan bahwa kandungan antosianin varietas Red Leaf (warna daun hijau - merah keunguan) memiliki kandungan antosianin yang lebih sedikit dibandingkan 5 varietas bayam merah lainnya (warna daun merah keunguan). Rachmania \& Ashari (2019) juga melaporkan bahwa kandungan antosianin bayam merah lokal lebih tinggi dibandingkan bayam hijau varietas komersial.

Tabel 1. Persentase warnah merah, hijau dan biru daun berbagai varietas komersil bayam hijau dan merah

\begin{tabular}{|c|c|c|c|c|c|c|}
\hline \multirow{2}{*}{$\begin{array}{r}\text { Varietas } \\
\text { Bayam hijau: }\end{array}$} & \multicolumn{2}{|c|}{ Merah (\%) } & \multicolumn{2}{|c|}{ Hijau (\%) } & \multicolumn{2}{|c|}{ Biru (\%) } \\
\hline & & & & & & \\
\hline Maryland & 39,18 & bcd & 56,83 & $a b$ & 3,99 & de \\
\hline Richie & 37,21 & de & 53,63 & $c d$ & 9,16 & $a b$ \\
\hline Maestro & 40,25 & $b c$ & 55,73 & $a b c$ & 4,02 & de \\
\hline Benua & 38,15 & cde & 56,98 & a & 4,87 & $\mathrm{~cd}$ \\
\hline Doly & 38,65 & bcde & 54,40 & bcd & 6,95 & bcd \\
\hline Khanafiah & 36,39 & e & 52,34 & d & 11,27 & a \\
\hline Manila & 40,50 & $a b$ & 54,81 & abcd & 4,69 & cde \\
\hline Pacific & 36,88 & de & 55,44 & $a b c$ & 7,68 & $a b c$ \\
\hline White leaf & 42,76 & a & 56,06 & $a b c$ & 1,19 & e \\
\hline \multicolumn{7}{|l|}{ Bayam merah: } \\
\hline Mira & 45,34 & $a$ & 27,73 & $a$ & 26,93 & $a$ \\
\hline Baret merah & 45,93 & $a$ & 27,46 & $a$ & 26,61 & $a$ \\
\hline Clara & 46,33 & $\mathrm{a}$ & 27,18 & $\mathrm{a}$ & 26,49 & $a$ \\
\hline Aurora & 46,58 & $\mathrm{a}$ & 26,97 & $\mathrm{a}$ & 26,45 & $\mathrm{a}$ \\
\hline Hijau vs merah & $* *$ & & $* *$ & & $*$ & \\
\hline
\end{tabular}

Keterangan: Huruf yang berbeda dalam kolom bayam hijau berbeda nyata berdasarkan uji BNJ $\alpha$ 5\%, *Berbeda nyata berdasarkan uji kontras pada taraf $\alpha 5 \%,{ }^{* *}$ Berbeda nyata berdasarkan uji kontras pada taraf $\alpha 1 \%$ 


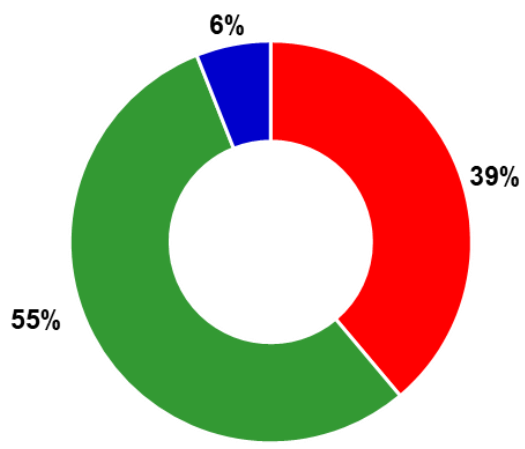

A

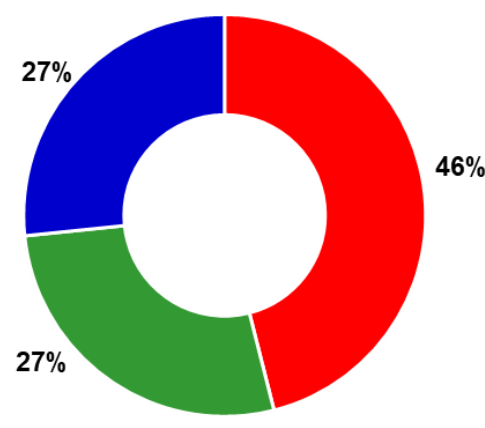

B

Gambar 1. Persentase warna merah, hijau dan biru pada daun A) Bayam hijau, B) Bayam merah

Varietas bayam hijau yang berbeda menghasilkan tinggi tanaman yang berbeda pada 2 dan 3 minggu setelah tanam (MST), sedangkan varietas bayam merah hanya menghasilkan perbedaan tinggi tanaman pada 3 MST (Tabel 2). Perbedaan tinggi tanaman pada varietas bayam hijau diduga lebih besar dipengaruhi oleh faktor genetik sedangkan perbedaan tinggi tanaman pada varietas bayam merah diduga lebih besar dipengaruhi oleh faktor lingkungan.

Tabel 2. Tinggi Tanaman dan Umur Panen Berbagai Varietas Komersil Bayam Hijau dan Bayam Merah

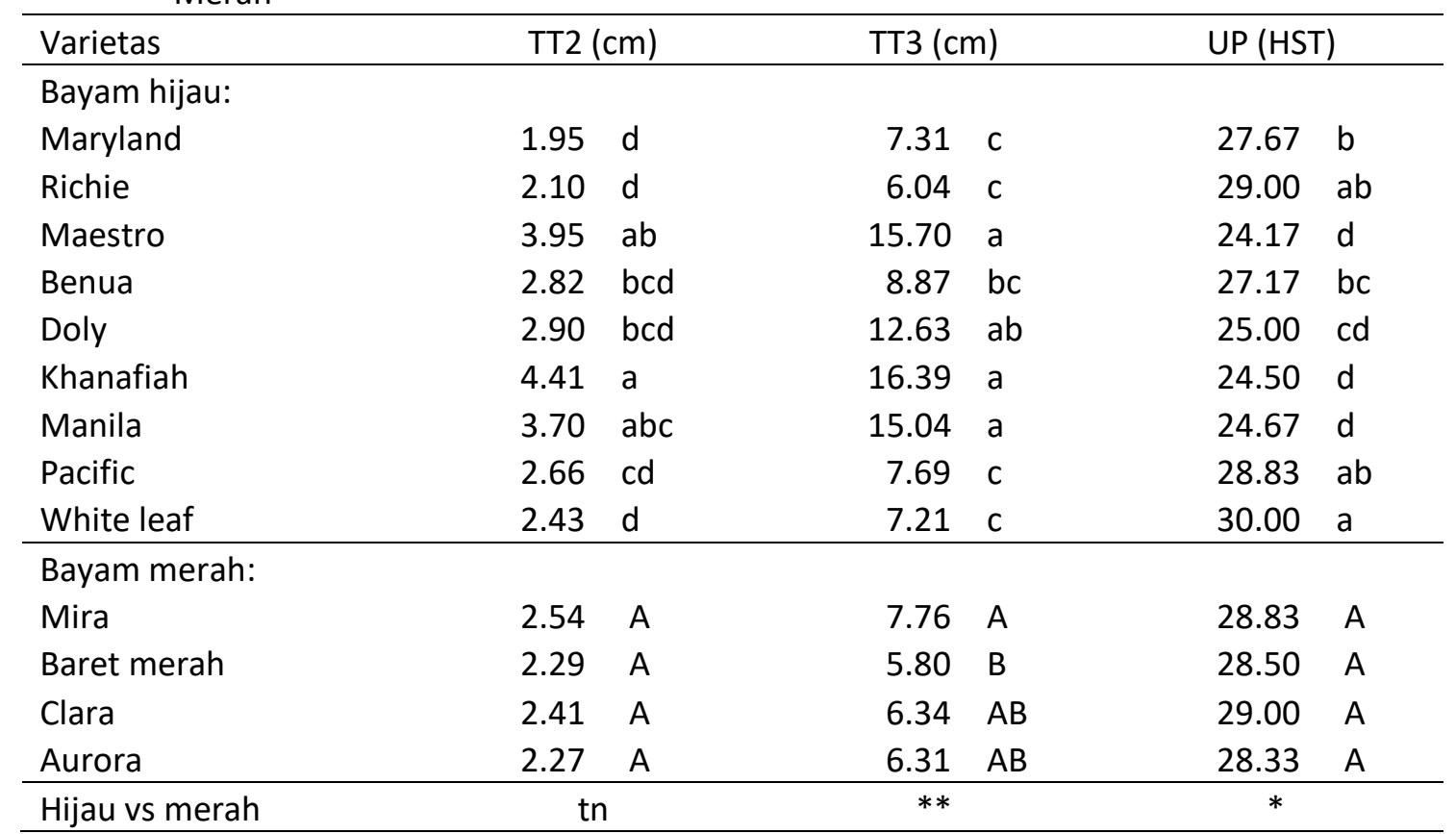

Keterangan: Keterangan: Huruf kecil yang berbeda dalam kolom varietas bayam hijau berbeda nyata berdasarkan uji BNJ $\alpha 5 \%$, Huruf kapital yang berbeda dalam kolom varietas bayam merah berbeda nyata berdasarkan uji BNJ $\alpha 5 \%$, *Berbeda nyata berdasarkan uji kontras pada taraf $\alpha 5 \%$, ** Berbeda nyata berdasarkan uji kontras pada taraf $\alpha 1 \%, \mathrm{tn}=$ Tidak berbeda nyata berdasarkan uji kontras pada taraf $\alpha$ $5 \%, \mathrm{TT} 1$ = Tinggi tanaman pada 2 minggu setelah tanam, $T$ T3 = Tinggi tanaman pada 3 minggu setelah tanam, UP = Umur panen, HST = Hari setelah tanam. 
Aritonang \& purnamaningsih (2018) dalam publikasinya menyakatan bahwa keragaman genetik untuk karakter tinggi tanaman dari lima populasi bayam merah yang dievaluasi tergolong rendah.

Umur panen varietas bayam hijau lebih genjah dibandingkan bayam merah pada penelitian ini (Gambar 2). Umur panen genjah dapat lebih menguntungkan bagi petani karena dapat meningkatkan indeks pertanaman dan biaya produksi serta mengurangi resiko gagal panen tanaman budidaya akibat cekaman biotik atau abiotik (Rahajeng \& Adie, 2013; Azizah et al., 2017). Varietas bayam hijau lebih cepat panen karena memiliki pertumbuhan tinggi tanaman yang lebih cepat dibandingkan varietas bayam merah (Gambar 2). Semakin cepat pertumbuhan tinggi tanaman maka semakin cepat umur panen pada tanaman bayam (Kendre et al., 2014).
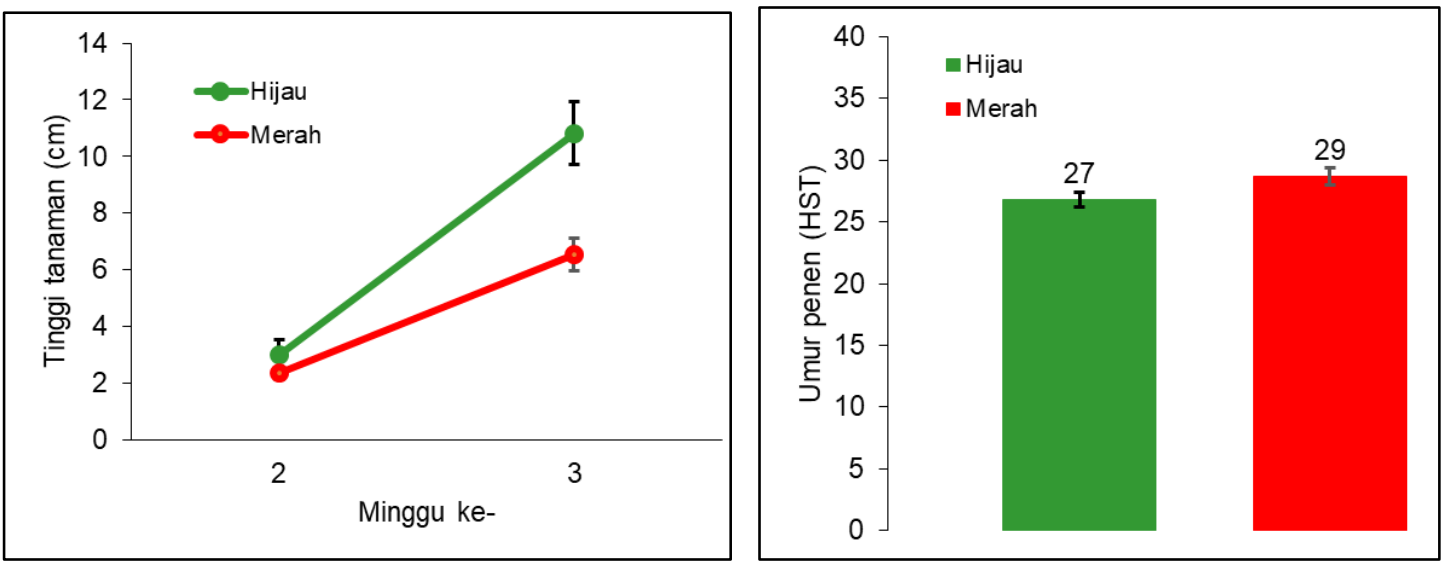

Gambar 2. Tinggi tanaman dan umur panen varietas bayam hijau dan bayam merah

Pertumbuhan tinggi tanaman yang lebih cepat diduga berhubungan dengan kandungan klorofil di dalam daun. Song et al. (2020) melaporkan bahwa terdapat korelasi yang nyata dan positif antara kandungan klorofil total dengan laju fotosintesis pada tanaman mentimun. Selain itu, telah dilaporkan juga bahwa kandungan klorofil memiliki korelasi yang nyata dan negatif dengan kandungan beta karoten pada daun bayam (Sarker et al., 2020), sedangkan kandungan beta karoten daun memiliki korelasi yang nyata dan negatif terhadap tinggi tanaman bayam (Sarker et al., 2014). Varietas bayam hijau memiliki persentase warna hijau daun yang lebih tinggi sehingga diduga juga memiliki kandungan klorofil yang lebih tinggi dibandingkan varietas merah. Hal ini menyebabkan pertumbuhan tinggi dan umur panen varietas bayam hijau lebih cepat dibandingkan varietas bayam merah.

Terdapat variasi diameter batang, panjang, lebar dan luas daun pada varietas bayam hijau dan varietas bayam merah (Tabel 3). Hal ini mengindikasikan adanya keragaman genetik yang tinggi untuk karakter diameter batang, panjang, lebar dan luas daun pada varietas bayam hijau dan varietas bayam merah. Rashid et al. (2020) melaporkan bahwa karakter daun (panjang, lebar dan luas daun) serta diameter batang termasuk karakter utama yang berkontribusi dalam tingginya keragaman genetik 200 genotipe bayam. Keragaman yang tinggi pada karakter daun 
bayam diduga berhubungan dengan pola konsumsi masyarakat. Bagian daun merupakan bagian utama dari tanaman bayam dikonsumsi oleh masyarakat (Segheloo et al., 2014). Hal ini menyebabkan pemuliaan tanaman bayam banyak diarahkan pada peningkatan kualitas dan kuantitas daun bayam. Menurut Sabaghnia et al. (2016) karakter panjang, lebar dan luas daun merupakan karakter yang sangat baik digunakan dalam seleksi indeks dalam meningkatkan produktivitas tanaman bayam. Ribera et al. (2020) dalam tinjauannya manyampaikan bahwa pemuliaan tanaman bayam pada pertengahan abad 20 lebih banyak diarahkan pada daun bayam berwarna hijau gelap dan bentuk yang bulat.

Tabel 3. Diameter Batang, Jumlah Daun per Tanaman, Panjang Daun, Lear Daun, Luas Daun Dan Panjang Tangkai Daun Berbagai Varietas Komersil Bayam Hijau dan Merah

\begin{tabular}{|c|c|c|c|c|c|c|c|c|c|c|c|c|}
\hline \multirow{2}{*}{$\begin{array}{l}\text { Varietas } \\
\text { Bayam Hijau: }\end{array}$} & \multicolumn{2}{|c|}{$\mathrm{DB}(\mathrm{cm})$} & \multicolumn{2}{|c|}{ JDP } & \multicolumn{2}{|c|}{ PD (cm) } & \multicolumn{2}{|c|}{$\mathrm{LD}(\mathrm{cm})$} & \multicolumn{2}{|c|}{$\operatorname{LUD}\left(\mathrm{cm}^{2}\right)$} & \multicolumn{2}{|c|}{ PTD (cm) } \\
\hline & & & & & & & & & & & & \\
\hline Maryland & 0,51 & bc & 7,62 & e & 7,29 & de & 6,77 & $a$ & 59,48 & $a$ & 4,96 & $a b$ \\
\hline Richie & 0,56 & $a b c$ & 9,02 & bcd & 10,44 & a & 4,49 & c & 50,66 & $a b$ & 4,92 & $a b$ \\
\hline Maestro & 0,61 & a & 8,25 & de & 9,44 & $a b$ & 7,11 & a & 56,55 & $a b$ & 5,13 & a \\
\hline Benua & 0,58 & $a b$ & 9,72 & $a b$ & 8,44 & bcd & 7,31 & a & 65,11 & a & 4,35 & $a b$ \\
\hline Doly & 0,58 & $a b$ & 8,47 & cde & 9,12 & b & 6,92 & a & 63,82 & a & 5,16 & $a$ \\
\hline Khanafiah & 0,53 & $a b c$ & 9,17 & abcd & 7,80 & cde & 5,58 & b & 32,91 & b & 4,42 & $a b$ \\
\hline Manila & 0,57 & $a b c$ & 8,35 & cde & 9,04 & $b c$ & 6,85 & a & 51,31 & $a b$ & 4,91 & $a b$ \\
\hline Pacific & 0,61 & a & 10,17 & a & 8,60 & $b c$ & 7,19 & $a$ & 53,56 & $a b$ & 4,29 & $a b$ \\
\hline White leaf & 0,49 & c & 9,38 & $a b c$ & 6,82 & e & 7,55 & a & 63,92 & a & 4,17 & b \\
\hline \multicolumn{13}{|c|}{ Bayam merah: } \\
\hline Mira & 0,50 & B & 9,45 & A & 7,88 & B & 5,93 & B & 64,67 & B & 3,86 & B \\
\hline Baret merah & 0,60 & A & 10,08 & A & 9,19 & A & 6,87 & A & 70,52 & $A B$ & 4,27 & $A B$ \\
\hline Clara & 0,56 & A & 10,07 & A & 8,74 & $A B$ & 6,61 & $A B$ & 65,25 & B & 4,04 & B \\
\hline Aurora & 0,61 & A & 10,25 & A & 9,40 & A & 7,00 & A & 83,22 & A & 4,51 & A \\
\hline Hijau & 0,56 & & 8,93 & & 8,58 & & 6,64 & & 54,59 & & 4,69 & \\
\hline \multirow[t]{2}{*}{ Merah } & 0,57 & & 9,96 & & 8,80 & & 6,60 & & 70,91 & & 4,17 & \\
\hline & tn & & $* *$ & & tn & & tn & & $* *$ & & $* *$ & \\
\hline
\end{tabular}

Keterangan: Keterangan: Huruf kecil yang berbeda dalam kolom varietas bayam hijau berbeda nyata berdasarkan uji BNJ $\alpha 5 \%$, Huruf capital yang berbeda dalam kolom varietas bayam merah berbeda nyata berdasarkan uji BNJ $\alpha 5 \%$, *Berbeda nyata berdasarkan uji kontras pada taraf $\alpha 5 \%$, ** Berbeda nyata berdasarkan uji kontras pada taraf $\alpha 1 \%$, tn = Tidak berbeda nyata berdasarkan uji kontras pada taraf $\alpha$ $5 \%, \mathrm{DB}=$ Diameter batang, JDP = Jumlah daun per tanaman, PD = Panjang daun, LD = Lebar daun, LUD = Luas daun, PTD = Panjang tangkai daun

Hasil uji kontras memperlihatkan bahwa varietas bayam hijau memiliki jumlah daun per tanaman lebih sedikit dan luas daun yang lebih kecil dibandingkan varietas bayam merah (Tabel 3). Kandungan klorofil pada varietas bayam merah lebih rendah dibandingkan pada varietas bayam hijau.
Hal ini diduga menyebabkan tanaman bayam merah beradaptasi meningkatkan ukuran luas daun dan jumlah daun per tanaman agar dapat meningkatkan jumlah klorofil tanaman sehingga fotosisntesis dan produksi tanaman menjadi lebih optimal. Terdapat korelasi yang nyata dan positif 
antara jumlah daun per tanaman dengan kandungan klorofil daun pada tanaman nilam (Nurmayanti et al., 2021).

Tabel 4 Bobot per Tanaman dan Produktivitas Berbagai Varietas Komersil Bayam Hijau dan Merah

\begin{tabular}{|c|c|c|c|c|}
\hline Varietas & \multicolumn{2}{|c|}{$\mathrm{BBT}(\mathrm{g})$} & \multicolumn{2}{|c|}{$\mathrm{BBH}\left(\mathrm{t} \mathrm{ha}^{-1}\right)$} \\
\hline \multicolumn{5}{|l|}{ Bayam hijau: } \\
\hline Maryland & 8,3 & c & 24,3 & $\mathrm{~cd}$ \\
\hline Richie & 10,2 & $b c$ & 36,4 & $\mathrm{a}$ \\
\hline Maestro & 16,3 & a & 31,6 & abcd \\
\hline Benua & 12,0 & bc & 31,7 & abcd \\
\hline Doly & 13,3 & $a b$ & 27,0 & $\mathrm{bcd}$ \\
\hline Khanafiah & 12,3 & bc & 30,1 & abcd \\
\hline Manila & 13,3 & $a b$ & 32,7 & $a b c$ \\
\hline Pacific & 13,3 & $a b$ & 23,4 & $d$ \\
\hline White leaf & 8,6 & c & 34,2 & $a b$ \\
\hline \multicolumn{5}{|c|}{ Bayam merah: } \\
\hline Mira & 10,1 & $A$ & 27,0 & $A$ \\
\hline Baret merah & 12,6 & $A$ & 21,7 & $A$ \\
\hline Clara & 11,9 & $A$ & 23,0 & $A$ \\
\hline Aurora & 13,5 & $A$ & 23,2 & $A$ \\
\hline $\begin{array}{l}\text { Hijau vs } \\
\text { Merah }\end{array}$ & \multicolumn{2}{|l|}{ tn } & \multicolumn{2}{|c|}{$* *$} \\
\hline
\end{tabular}

Keterangan: Huruf kecil yang berbeda dalam kolom varietas bayam hijau berbeda nyata berdasarkan uji BNJ $\alpha 5 \%$, Huruf kapital yang berbeda dalam kolom varietas bayam merah berbeda nyata berdasarkan uji BNJ $\alpha 5 \%, * *$ Berbeda nyata berdasarkan uji kontras pada taraf $\alpha 1 \%$, tn = Tidak berbeda nyata berdasarkan uji kontras pada taraf $\alpha 5 \%$, BBT = Bobot per tanaman, $\mathrm{BBH}=$ Produktivitas

Prasundari et al. (2018) melaporkan bahwa tanaman petunia yang memiliki indeks klorofil lebih rendah (tipe Grandiflora) memiliki luas daun yang lebih besar dibandingkan petunia yang memiliki indeks klorofil lebih tinggi (tipe Multiflora). Tanaman toleran naungan meningkatkan efisiensi fotosintesis dengan meningkatkan klorofil tanaman melalui peningkatan luas daun dan jumlah daun per tanaman (Pantilu et al., 2012; Ritonga et al., 2019). Hasil uji kontras juga memperlihatkan bahwa varietas bayam hijau memiliki panjang tangkai daun yang lebih panjang dibandingkan varietas bayam merah.

Terdapat perbedaan bobot per tanaman, dan produktivitas antar varietas bayam hijau (Tabel 4). Hal ini salah satunya dapat disebabkan karena adanya perbedaan pertumbuhan dan ukuran daun antar varietas bayam hijau. Terdapat korelasi yang nyata dan positif antara karakter panjang daun, lebar daun, tinggi tanaman, dan diameter batang terhadap produktivitas tanaman bayam (Ahammed et al., 2012; Hasan et al., 2013). Menurut Sabagnia et al. (2014), bayam merupakan sayuran yang dipanen daun segarnya sehingga ukuran daun dan jumlah per tanaman sangat mempengaruhi produktivitas tanaman.

Hal yang berbeda dihasilkan oleh varietas bayam merah. Tidak terdapat perbedaan bobot per tanaman dan produktivitas yang signifikan antar varietas bayam merah (Tabel 4). Hal ini dapat disebabkan oleh bobot batang antara varietas bayam merah yang diduga tidak berbeda. Hasan et al. (2013) melaporkan bahwa bobot batang memiliki pengaruh langsung yang kuat dan positif terhadap hasil tanaman bayam. Varietas bayam merah Mira memiliki tinggi tanaman yang lebih tinggi namun memiliki diameter batang yang lebih kecil dibandingkan ketiga varietas bayam merah. Ahammed et al. (2012) melaporkan bahwa terdapat korelasi yang nyata dan positif antara panjang dan diameter batang terhadap bobot batang pada tanaman bayam.

Hasil uji kontras terhadap karakter hasil memperlihatkan bahwa produktivitas bayam hijau lebih tinggi dibandingkan bayam merah (Gambar 3). Kandungan 
klorofil daun pada varietas bayam hijau diduga dapat menyebabkan produktivitas bayam hijau lebih tinggi dibandingkan varietas bayam merah. Sarker et al. (2018) melaporkan adanya korelasi yang sangat nyata dan positif antara kandungan klorofil daun dan produktivitas pada tanaman bayam. Selain itu, ukuran tanaman juga diduga dapat menyebabkan perbedaan produktivitas bayam hijau dan bayam merah. Ukuran tinggi tanaman bayam merah yang lebih pendek dengan luas daun yang lebih besar dibandingkan bayam hijau menyebabkan adanya kompetisi cahaya yang lebih tinggi antara tanaman pada varietas bayam merah sehingga menyebabkan tidak semua tanaman tumbuh optimal pada varietas bayam merah. Hal ini diindikasikan dengan bobot per tanaman yang tidak berbeda nyata antara varietas bayam hijau dan bayam merah walaupun bobot per bedeng dan produktivitasnya berbeda nyata. Menurut Hadi (2018), kompetisi cahaya terjadi saat suatu tanaman menaungi tanaman lainnya atau suatu daun menaungi daun yang lainnya sehingga mempengaruhi proses fotosintesis tanaman. Teknik "sebar dalam alur" pada budidaya tanaman bayam menyebabkan meningkat-nya potensi kompetisi cahaya antar tanaman khususnya pada tanaman dengan daun yang lebar. Menurut Sari et al. (2016), kompetisi cahaya dipengaruhi oleh beberapa faktor yaitu bentuk daun, luas tajuk dan tinggi tanaman. Daun dan luas tajuk yang besar meningkatkan kompetisi cahaya, sedangkan tinggi tanaman yang lebih tinggi mampu mengurangi tingkat kompetisi cahaya.

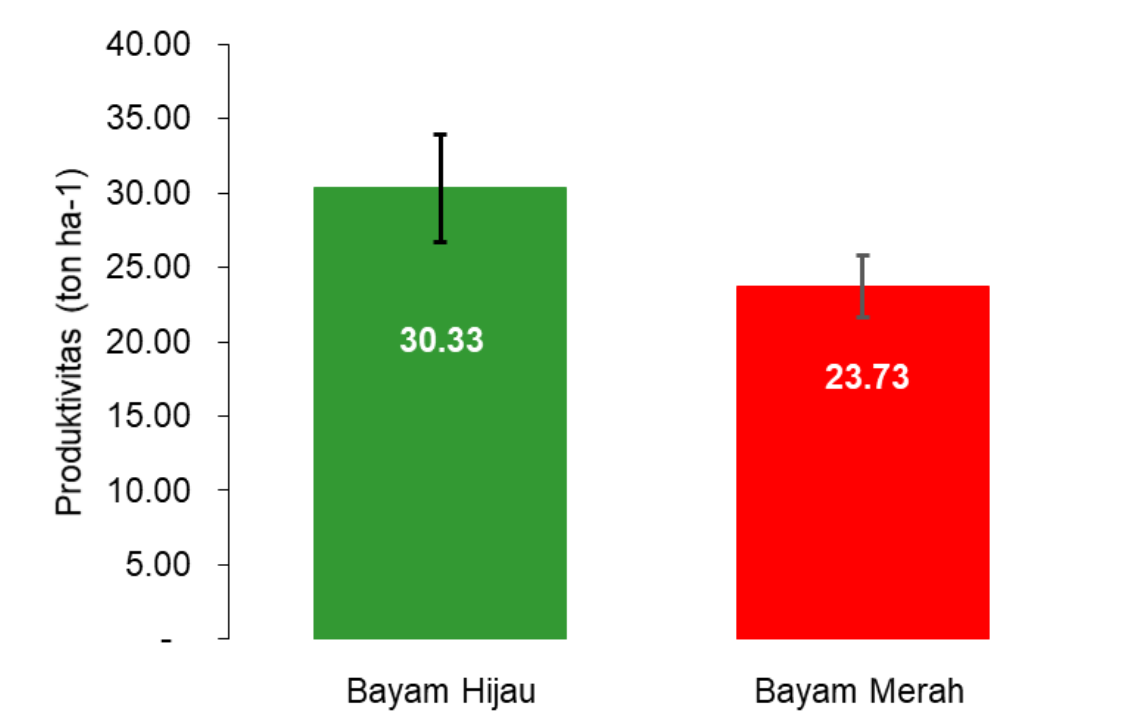

Gambar 3. Produktivitas varietas bayam hijau dan bayam merah

Varietas bayam White Leaf merupakan varietas yang sangat baik berdasarkan penelitian ini. Varietas white Leaf memiliki \% warna hijau daun yang tinggi, luas daun yang besar dan produktivitas yang tinggi. Fajarani et al. (2021) melaporkan bahwa konsumen lebih sayuran daun berwarna hijau muda, kesegaran lebih lama, serta daun lebar yang tidak berlubang. 


\section{SIMPULAN}

1. Varietas bayam hijau memiliki kandungan persentase warna hijau daun lebih banyak namun memiliki persentase warna biru dan merah daun yang lebih rendah dibandingkan varietas bayam merah.

2. Varietas bayam hijau menghasilkan tinggi tanaman dan produktivitas yang lebih baik dibandingkan varietas bayam merah, namun menghasilkan luas daun dan jumlah daun per tanaman saat panen yang lebih kecil dibandingkan varietas bayam merah.

3. Varietas bayam White Leaf merupakan varietas yang sangat baik karena memikiki \% warna hijau daun yang tinggi, luas daun yang besar dan produktivitas yang tinggi.

\section{DAFTAR PUSTAKA}

Ahammed, A.U., Rahman, M.M., Mian, M.A.K. (2012). Genetic variability, heritability and correlation in stem amaranth (Amaranthus tricolor). Bangladesh J. Pl. Breed. Genet., 25(2),25-32.

Aritonang, A.M. \& Puenamaningsih, S.L. (2018). Heritabilitas karakter agronomi pada lima populasi bayam merah (Amaranthus tricolor L.). Jurnal Produksi Tanaman, 6(10), 2431-2438.

Azizah, H.A.N., Wicaksana, N., Ruswandi, D. (2017). Seleksi kacang Bambara (Vigna ubterranea L.) berumur genjah hasil iradiasi gamma generasi M2. Agrologia, 6(2), 84-92.

[BPS] Badan Pusat Statistika. (2019). Produksi Tanaman Sayuran 2019. [diunduh 2021 Oktober 13]. https://www.bps.go.id/indicator/55/ 61/1/produksi-tanaman-sayuran.html
Fajarani, E., Elisa, W., Putri, N.E. (2021). Preferensi konsumen terhadap keputusan pembelian sayuran organik di supermarket diamond Kota Palembang. Jurnal Kaliagri, 2, 38-50.

Hadi, B.A. (2018). Pengaruh jarak tanam dan mulsa organic terhadap pertumbuhan dan hasil tanaman terung (Solanum melongena L.). Jurnal Warta, 56, 1-6.

Hasan, M., Akther, C.A., Raihan, M.S. (2013). Genetic variability, correlation and path analysis in stem Amaranth (Amaranthus tricolor L.) Genotypes. The Agriculturists, 11(1), 1-7.

Hasanah, B. \& Purnamaningsih, S.L. (2019). Korelasi dan sidik lintas komponen hasil dan hasil bayam merah (Amaranthus tricolor L.). Jurnal Produksi Tanaman, 7(5), 766-664.

Jauhari, T. \& Purnamaningsih, S.L. (2021). Keragaman genetik dan fenotipe pada dua populasi bayam hijau (Amaranthus hybridus L.). Jurnal Produksi Tanaman, 9(2), 140-144.

Jiang, C., Johkan, M., Hohjo, M., Tsukagoshi, S., Mario, T. (2017). A correlation analysis on chlorophyll content and SPAD value in tomato leaves. Hort Research, 71, 37-42.

Kendre, V.H., Dod, V.N., Nagre, P.K., Potdukhe, N.R., Kale, V.S. (2014). Genetic variability and correlation studies in leafy amaranth. PKV Res. J., 38(1), 14-17.

Manurung, F.S., Nurchayati, Y., Setiari, N. (2020). Pengaruh pupuk daun Gandasil D terhadap pertumbuhan, kandungan klorofil dan karotenoid tanaman bayam merah (Alternanthera amoena Voss.). Jurnal Biologi Tropika, 3(1), 24-32.

Nurmayanti, S., Tahir, M., Dianti, G.A.P. (2021). Variability, korelasi dan analisis kelas sepuluh genotipe nilam (Pogostemon cablin Benth.). Agosainstek, 5(1), 81-88. 
Pantilu, L.I., Mantiri, F.R., Ai, N.S., Pandiangan, D. (2012). Respons morfologi dan anatomi kecambah kacang kedelai (Glycine max L.) terhadap intensitas cahaya yang berbeda. Jurnal Bioslogos, 2(2), 79-86.

Pebrianti, C., Ainurrasyid R.B., Purnamaningsih, S.L. (2015). Ujikadar antosianin dan hasil enam varietas tanaman bayam merah (Alternanthera amoena Voss) pada musim hujan. Jurmal Produksi Tanaman, 3(1), 27-33.

Pransundari, I.R. \& Sitawati, E.W. (2018). Syudi toleransi dua tipe tanaman petunia (petunia $x$ hibrida) terhadap naungan. Jurnal Produks Tanaman, 6(4), 569-578.

Rachmania, N. \& Ashari, S. (2019). Seleksi tanaman bayam merah (Amaranthus tricolor L.) lokal Malang. Jurnal Produksi Tanaman, 7(4), 720-727.

Rahajeng, W. \& Adie, M.M. (2013). Varietas kedelai umur genjah. Buletin Palawija, 26, 91-100.

Rahayu, S.T., Hidayat, A.A., Kusmana, I.M., Diny, D. (2013). Evaluasi Kualitas Beberapa Genotipe Bayam (Amaranthus sp) Pada Penanaman Di Jawa Barat. Berita Biologi, 12(2), 153160.

Rashid, M., Yousaf, Z., Ullah, M.N., Munawar, M., Riaz, N., Younas A., Aftab, A., Shamsherr B. (2020). Genetic variability assessment of worldwide spinach accession by agrmorphological. Journal of Taibah University for Science, 14(1), 16371650.

Reddy, M.T., Begum, H., Sunil, N., Rao, P.S., Sivaraj, N., Kumar, S. (2014). Preliminary characterization anc evaluation of landrace of indian spinach (Basella spp. L) for agroeconomic and quality traits. Plant Breed. Biotech, 2(1), 48-63,
http://dx.doi.org/10.9787/PBB.2014. 2.1.048

Ribera, A., Bai, Y., Wolterss A.M.A., Treuren, R.V., Kik, C. (2020). A revies on the genetic resources, domestication and breeding history of spinach (Spinacia oleracea L.). Euphytica, 48,216-236, https://doi.org/10.1007/s10681-02002585-y.

Sabaghnia, V., Mohebodini, M., Janmohammadi. (2016). Biplot analysis of trait relations of spinach (Spinancia leracea L). Genetika, 48(2),675-690, https://10.2298/GENSR1602675S

Ritonga, A.W., Chozin, M.A., Syukur, M., Maharijaya, A., Sobir. (2019). Heritabilitas, korelasi dan sidik lintas berbagai karakter tomat pada kondisi naungan dan tanpa naungan. J. Hort. Indonesia, 10(2), 85-93.

Sabaghnia, N., Hgarnneh, H.A.A., Janmohammadi, M. (2014). Genetic diversity of spinach (Spinacia oleracea L.) landrace collected in Iran using some morpholical traits. Acta Agriculturae, 103(1), 101-111, https://10.14720/aas.2014.103.1.11.

Sari, D.M., Sembodo, D.R.J., Hidayat, K.F. (2016). Pengaruh jenis dan tingkat kerapatan gulma terhadap pertumbuhan awal tanaman ubikayu (Manihot esculenta Crantz) Klon UJ-\% (Kasetsart). J. Agrotek Tropika, 4(1), 6.

Sarker, U., Islam, Md.T., Rabbani, Md.G., Oba, S. (2014). Genotypic variability for nutrient, antioxidant, yield, and tield contributing traits in vegetable amaranth. Science and Technology, 12(3-4), 168-174.

Sarker, U., Islam, Md.T., Rabbani, Md.G., Oba, S. (2018). Variability in total antioxidant capacity, antioxidant leaf pigments and foliage yield of 
vegetable amarantha. ScienceDirect, 17(5), 1145-1153.

Sarker, U., Oba, S., Daramy, M.A. (2020). Nutrient, minerals, antioxidant pigment and phytochemical, and antioxidant capacity of the leaves of stem amarantha. Scientific Reports, 10 , 3892-3901, https://doi.org/10.1038/s41598-02060252-7.

Satriyono, W. \& Ashari, S. (2019). Evaluasi tanaman bayam merah (Amaranthus tricolor). Jurnal Produksi Tanaman, 7(9), 1762-1766.

Segheloo, A.E., Gharbeh, H.A., Mohebodini, M., Janmohammadi M., Nouraein, M., Sabaghnia, N., (2014). The use of some morphological traits for the assessment of genetic diversity in spinach (Spinacia oleracea L) landrace. Plant Breeding and Seed
Science,

46,

46-57, https://10.1515/plass-2015-0007

Song, H., Li, Y., Xu, X., Zhan, J., Zheng, S., Hou, L., Xing, G., Li, M. (2020). Analysis of genes related to chlorophyll metabolism under elevated $\mathrm{CO} 2$ in cucumber (Cucumis sativus L.). Scientia Horticulturae, 261, 1-10, https://doi.org/10.1016/i.scienta.201 9.108988.

Wiyasihati, S.I. \& Wanito, W.K. (2016). Potensi Bayam Merah (Amaranthus tricolor L) Sebagai Antioksidan Pada Toksisitas Yang Diinduksi Pada Mencit. Majalah Kedokteran Bandung, 48(2), 63-67.

Zuryanti, D., Rahayu, A., Rochman, N. (2016). Pertumbuhan, produksi, dan kualitas bayam (Amaranthus tricolor L.) pada berbagai dosis pupuk kandang ayam dan kalium nitrat $\left(\mathrm{KNO}_{3}\right)$. J Agronida, 2(2), 98-105. 